\title{
People with Disabilities as Motivational Objects in the Kick Andy Talkshow Program: The Social Construction Approach of Reality Theory
}

\author{
Rizki Halim ${ }^{1 *}$ \\ ${ }^{1}$ Universitas Diponegoro, Semarang, Indonesia
}

Article Information

Submitted February 24, 2021

Revised July 23, 2021

Accepted August 25, 2021

Published October 01, 2021

\begin{abstract}
Most of the disability issues have not yet received proper representation in the media, even though quite a few people with disabilities in Indonesia. The depiction of persons with disabilities in the media often distorts them. Often people with disabilities with physical limitations are depicted incorrectly or even irrationally. The Social Construction of Reality (SCR) theory, introduced by Peter L. Berger and Thomas Luckmann, uses to analyze whether the Kick Andy television program supports the stigma of the disabled or can be a medium that changes the stigma that exists as constructs for the disabled-related community. Television viewers have a rationalistic cycle through three moments: externalization, objectivation, and internalization. This theory focuses on general meanings and constructions built by community groups to shape social order (rules, standards, values, and activities recognized in community groups). The study results show that guest stars with disabilities on the Kick Andy television program cannot separate from the social construction that has been formed in the community regarding their condition. The Kick Andy program also clarifies the social construction experienced by its guest stars, which uses as an object of motivation for the audience. The researcher found that the Kick Andy show, intentionally or unintentionally, still gave a lousy label to people with disabilities, even though the host then used the narration built as a background for inspiration.
\end{abstract}

Keywords: Disabilities; Kick Andy; Television Show, Social Construction

\section{Introduction}

Based on data recorded by the International Labor Organization (ILO), at least 15 per cent of the total population in the world today classifies as a person with a disability. From this figure, it can estimates that at least more than one billion people around the globe can categorize as persons with disabilities. Of this number, around $82 \%$ of persons with disabilities are in nonindustrialized countries, including Indonesia. At least based on data from the Central Bureau of Statistics (BPS) quoted from the Ministry of Social Affairs of the Republic of Indonesia (2020), as of 2020, the number of people with disabilities in Indonesia reaches 22.5 million or about five per cent of the total population of Indonesia.

Meanwhile, the World Health Organization (WHO) survey shows that the number of people with disabilities in Indonesia reaches 24 million people or about $10 \%$ of the total population of Indonesia.

\footnotetext{
*Author Correspondence: Rizki Halim, Fakultas Ilmu Sosial dan Politik, Universitas Diponegoro, Jalan Prof. Soedarto, S.H., Tembalang, Kota Semarang Kode pos 50275.
}

Copyright (C) 2021 Rizki Halim 
With such a large number, there has not been sufficient substantial information about the depiction of persons with disabilities in the mass media in Indonesia. This fact also shows that broad communication needs to consider the problem of persons with disabilities and academics who pay little attention to disability issues.

Most of the disability issues have not been covered by the media, even though the number of people with disabilities cannot be small. When the media does not cover problems that could affect the fate of millions of Indonesians and their families, it makes them almost invisible and thus hides the inequality they experience. (ILO, 2014).

Meanwhile, regarding the depiction of individuals with disabilities in the media or the lack of representation, two fundamental issues emerged so far are underrepresentation and misrepresentation. There are very few depictions of individuals with disabilities in the media, which makes us far from the truth about individuals with disabilities. The formation of disability group identity is a gradual process of personal identity, community identity, and disability group identity. The formation of disability identity in community media occurs through a construction process that involves various internal and external factors of the community. The built identity is dynamic (Nastiti, 2013).

The results of Nastiti's research are reinforced by the findings of other researchers, who examined the online mass media Suara Merdeka, which found that people with disabilities describe as marginalized from the main party in a piece of published news. There were still negative stereotypes in a marginalization process towards them ( Apny \& Hasfi, 2019).
The depiction in the media is also often distorted. There are inaccurate or even nonsensical depictions of people with physical limitations. There is an inappropriate or even unfair portrayal of persons with disabilities, which impacts their social position and public policies regarding the fulfilment of their rights (Zhang and Haller, 2013).

The lack of space given to persons with disabilities as a minority group causes them to marginalize. The marginalization caused by news texts results in groups' established ideological structure and requires perpetuating their establishment in society. (Joseph, 2020).

Marulitua, in his research, also mentions that the role of the mass media increasingly marginalizes people with disabilities. The media have a significant role in expanding the previously established stigma to grow precisely. Among the influence of the media, the stereotypes that once existed in society regarding people with physical limitations became increasingly refined and maintained. (Marulitua, 2017).

The media can be an effective tool to remove the stigma and myths in people with disabilities. The press can additionally develop awareness among people with disabilities and the public about the privileges of people with disabilities in terms of employment and engaging daily needs.

There are two extensive possibilities in the media industry in assigning roles to people with disabilities, specifically as a figure as the object of mockery or ridicule and as a source of inspiration or motivation. As people are considered "abnormal," the media will tend to give framing to make the disabled achievers an excellent model and should be admired. 
One of the media programs that regularly presents people with disabilities as objects of motivation is the Kick Andy Talkshow program. Kick Andy is a television program broadcast on Metro TV and facilitated by Andy F Noya as a senior journalist. The Kick Andy program on Metro TV is a program that proposes to motivate the audience. Kick Andy is a television show that broadcasts once a week and has a rebroadcast every weekend. This show raises issues in individuals' lives and the inspiring experience.

The KickAndy program can accommodate several television shows circulating on private TV in Indonesia by presenting true stories containing an educational, educative, and evocative value. The guest stars presented attained from various circles, including individuals who have physical or mental limitations as guest stars.

The Kick Andy program has been broadcast regularly on Metro TV since March 2006. This program started with the idea of the owner of the Metro TV television station, Surya Paloh, who was interested in Andy F Noya's ability when he produced a program on the Metro TV station. The Kick Andy talk show program encourages people to watch with heart and provides informative, inspiring, and educative television programs.

This study focuses on analyzing the portrayal of persons with disabilities by the media, especially in the Kick Andy talk show program using the Social Construction of Reality theory approach.

\section{Method}

This study examines the social construction of people with disabilities as guest stars on the Kick Andy talk show television program. This study also aims to determine whether the talk show perpetuates ten stereotypes that Paul Hunt has categorized in his research (1991). The ten stereotypes include: As a pathetic individual, Object of interest and crime, Criticism and cruelty, Extremely worrying, Desperate, Being ridiculed, Truly the worst enemy, Burden, Having weird sex, Inability to work in daily life.

This study uses a qualitative approach that aims to recognize stereotyping in persons with disabilities. The primary data in this study is a quote in the Kick Andy Talkshow as the object of study. The data obtained were analyzed using the Social Construction of Reality (SCR) theoretical approach introduced by Peter L. Berger and Thomas Luckmann. This research examines whether the Kick Andy television program supports the stigma of disabled people or can be a medium. That changes the stigma that exists construct for the disabled-related community. A review of relevant literature strengthens the analysis results accomplished to produce a more comprehensive understanding.

\section{Results}

\section{Social Construction of Reality}

Social Construction of Reality (SCR) is a contemporary sociological hypothesis proposed by Peter L. Berger and Thomas Luckmann. The Social Construction of Reality hypothesis finds on the constructivist worldview, which sees all current social truths as social developments. Truth in today's social life is created and communicated by people. We learn through our faculties, our instincts. We get it from different people and sources. 
Constructivism is seen as an individual's cognitive work to interpret reality because there are social relations between individuals and the environment. Then the individual builds his knowledge of the truth he sees, based on a pre-existing knowledge structure, which Piaget (cognitive psychologist) calls a schema or schemata. This kind of constructivism is called social construction (Berger and Luckmann, 2013).

The constructionism theory or social construction introduction by Berger and Luckmann through their book, "The Social Construction of Reality." In his discourse in the media, there are five basic suggestions from the hypothesis of social constructionism, specifically;

1. Society is a construct, not a fixed reality

2. The media provide materials for the process of social construction

3. Meanings offered by the media but can be negotiated or rejected

4. Media reproduce specific meanings

5. Media cannot provide objective social reality because all facts are interpretations.

Edmund Husserl and Alfred Schutz strongly influence Berger's phenomenology. According to Berger and Luckmann (1990), proper knowledge or common sense is the knowledge shared with people in the routines of daily life.

Furthermore, Berger and Luckmann note that their ideas on human information science are influenced by Marx's twin notion of "substructure/superstructure." The idea of twins then, at that point, began to give rise to interpretive discussions. Marx would generally distinguish "substructure" only from economic design. Then, "superstructure" is considered a direct reflection of it.
According to Berger and Luckman, an individual will experience three moments of a rationalist cycle. Externalization, objectification, internalization. These three things usually don't appear in sequence. Still, as a society and every part of it goes through these three moments, it is ultimately necessary to perform a characterization process.

In externalization, which is explained by Berger and Luckmann (2013), it is stated that social order is a product produced by humans, or rather a contingent human production. It is made by humans and then takes place continuously.

Experiences experienced continuously will lead everyone to have a specific encapsulation and can be communicated through explicit standards of behaviour when dealing with other people.

Externalization and objectification are moments in a dialectical process that takes place continuously. In this case, the social group becomes an intermediary for objectification to be understood as reality by its members. Information about society is a simple example of multiple perspectives, mainly generalized and continually conveyed truth.

In the last dialectical process or internalization, Berger and Luckmann show that the individual is not born a society member. Still, he is born with a predisposition (tendency) towards sociality, and he is always a member of the community.

Internalization is the starting point of the time sequence. In the sense that there is an implied meaning shown from other people's emotional cycles, which can then be abstractly significant for that person. To achieve internalization, people will initially 
get socialization, distinguished as a thorough and continuous individual effect.

SCR theory includes tradition or sociocultural metatheory (sociocultural). It focuses on building identity through interactions in social groupssocioculturalists focus on how identity negotiate among situations. Culture is also an essential part of social interactions (Littlejohn \& Foss, 2009). This hypothesis focuses on general meanings and constructions built by community groups in developing social order (rules, standards, values, activities recognized in community groups).

The application of SCR is in line with the fact that the mass media still provides space to see people with disabilities as human objects whose degrees are lower than humans who have perfect physiques. The growing stereotypes about people with disabilities are inseparable from the role of the media. The role of the media is strengthening the portrayal of people with disabilities as those who are considered imperfect.

SCR theory tries to understand the importance of meaning, norms, roles, and work rules in communication. This theory focuses more on how individuals create reality as a whole. In social constructionism, symbolic interactionism has a tremendous influence on the existing image.

According to Berger and Luckmann's theoretical perspective, the cycle of development occurs through the argumentative social collaboration of the three types of reality, particularly: subjective reality, symbolic reality, and objective reality. This reality happens in interaction with three concurrent moments: externalization, objectification, and internalization.
Based on a rational cycle of moments, television viewers have a perspective or sensation that has no physical form. James Carrie described this social construction as a combination of four phases.

1. Construction. Social actors develop concepts into reality. Knowledge is regularly still invisible

2. Maintenance. People require to maintain the social construction to keep it going actively. If it is no longer relevant, the social structure will decrease and ignore. So, social meaning changes or decreases if it is less maintained.

3. Improvement of social actors. People need to improve construction because aspects may forget, changing over time.

4. Change. Constructs run simultaneously to send messages that may no longer be supported, so changes need the next generation (Littlejohn \& Foss, 2009).

With the stigma still attached to people with disabilities, in this case, is the Kick Andy show hope that it can influence the audience at the repair and change stage. If the media ignore this role, the bad stigma that has gone through the moment of internalization on its viewers will thrive.

The common thread of the thoughts of Berger and Luckmann is that humans and society are products that are dialectical, dynamic, and plural continuously. Reality is not static and definitive but emotional and dialectical. So it is fascinating to explore whether the media takes a role in changing the stigma that has thrived in the audience or can make changes in Carey's repair and change stages.

People with disabilities suffer complex difficulties and injustices. The stigma that claspe by society as a 'disabled individual' 
makes the individuals with disabilities perceived as detrimental, imperfect individuals, to the point of poor value and quality as human beings.

Distortion of facts or disparaging matters to people with disabilities in the media creates different issues for people with disabilities. Assuming that the media gives a new perspective to its viewers, what is introduced will be inaccurate in describing the representation of disability when the media fails to describe it adequately.

Their shortcomings or generalizations in society often accompany the presence of persons with disabilities in the media. Frequently they appear as objects of mercy or as someone outstanding from their unprecedented achievements. Furthermore, because their accomplishments disassociate from different limitations, maybe many people feel that making motivational objects for people with disabilities is ideal for describing what the media should do. People with disabilities are barely objects of evocative figures.

So far, people with disabilities have been objectified as a person or group of people, which is merely instrumental. In the description of objectification, they are excited because they have limitations, but they do not give up or can do tasks like "normal" people.

The media can be an intermediary when detailing an experience and revealing a particular perspective on understanding a phenomenon. The press in its system will develop and design audience awareness that has social and political results (Halimatusadiah, 2017)

Instead of helping disabled groups claim their rights as citizens, the mass media prefer to sympathize with them or use them as material to discuss their strengths in a proper context. People with disabilities are often perceived as motivation objects that transcend and are impeccable, making viewers forget that many people with disabilities are still marginalized.

\section{Disabled Stereotypes}

The generalization of individuals with disabilities has been described as negatively stigmatized and providing a disparaging perspective. In a report by The British Council of Organizations of Disabled People, Paul Hunt identifies ten generalizations that the media frequently relate to describe incapacitated individuals (Barnes, 1992):

1. As a pathetic individual

2. Objects of interest and crime

3. Criticism and cruelty

4. Very worrying

5. Conveyor of despair

6. Being laughed at

7. Truly the most terrible enemy

8. Burden

9. Having weird sex

10. Unable to work in daily life

The media has a role in constructing persons with disabilities as different individuals and framing the role of each individual who excludes in the "normal" construction. "These images affect not only people's judgments but also the self-concept of each person with a disability." (Haller, 2010)

It is undeniable that, like any other industry, the entertainment industry attempts to profit by taking as few risks and losses as possible. Based on this concept, the mass media tend to carry out rules, assumptions, and routines that are considered beneficial 
(Fursich, 2010). So far, the media have often played an essential role in protecting generalizations and characterizing "fair roles" for individual sections and associations of society.

Media content impacts the development of reality with language as the primary tool. A language is a tool for delivering massage. Thus, extensive communication by the mass media has a tremendous opportunity to influence what is framed as truth (Aini, 2020).

\section{Discussion}

Kick Andy television program regularly presents people with disabilities as guest stars. In talk shows, the presenters frequently ask questions inseparable from the various stigmata of people with disabilities. For example, in the episode "A Sharing Heart", Andy asked Windoyo, a blind man from Banyuwangi, inspiring because he could empower disabled groups in Banyuwangi. "As for Mas Win himself, how do you deal with when you are seven years old, your eyes still normal, then you are blind at 15 years old, how can you strengthen yourself to be able to get up?" Andi asked when digging about the beginning of Windoyo's blindness.

Andy's question falls into stereotyping, which Paul categorizes because he considers the disability condition the worst enemy even for themselves. So that makes the situation experienced by people with disabilities is very difficult to accept for ordinary people.

Still, in the same episode, Andy also asked Windoyo's wife, Indah. He asked why Indah finally wanted to marry Windoyo, who has physical limitations. "I'm sorry, everyone, both men and women, of course, expect to get a life partner who is physically and mentally perfect, so what made you fall in love at that time and be more willing to become a life partner," Andy said to Indah in the episode. The episode is as shown in Figure 1 below.

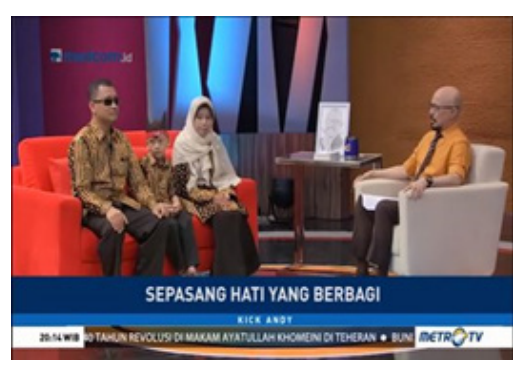

Figure 1. Windoyo and Indah in the episode "A Pair of Sharing Hearts."

Although the depiction of persons with disabilities in Figure 1 is not a tendentious question, the statement certainly strengthens the stereotype that marrying a person with a disability is not reasonable. Physical limitations consider abnormal, and marrying such a person is recognized not according to society's norms.

In the episode "Nothing Impossible", which starred a painter with a disability, Agus Yusuf, Andy also asked how the disabled spent their youth. "My childhood, my school years, I often heard that physically imperfect children were often played with, made fun of, bullied, did you experience that situation or not?". This question also emphasizes that people with disabilities in social life are the object of ridicule.

Agus, a painter without hands, also told how his parents never accepted him because of his physical imperfections that had been already since birth. "I was born in this form (disabled). My mother has been crying for three months". Agus's answer became an attractive angel for Kick Andy in leading the audience and further clarified that many parents are not mentally prepared if they have children with disabilities according to the negative and 
scary stereotype categorized as Paul Hunt.

Still in the same episode, on the sidelines of his interview, Andy said that many parents are ashamed of their children's condition who have physical and mental limitations. "If you see that many parents want to hide their children, if their children are born not physically perfect, many parents are embarrassed," said Andi when interviewing his guest star. The episode about the disabled painter is shown in Figure 2.

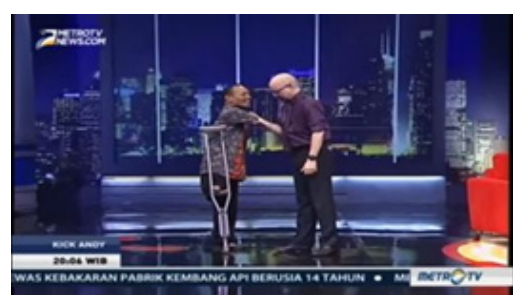

Figure 2. Agus Yusuf, in the episode "Nothing Impossible."

Kick Andy also stereotypes that being disabled is very sad and difficult to accept, as shown in the episode in Figure 2. Similar stereotypes still occur in another episode. Andy F. Noya invites Hasan Basri to "Disability is Not The Doomsday". Hasan, a retired billboard installation worker, used to be physically complete, but after an accident at work, he had to live the rest of his life without his hands.

"When going to be amputated, the first thing you imagined would be living without both hands. What was the scariest thing in your life? What did you imagine?" Andy said to Hasan, who is now a businessman. The question emphasizes that disabled people without hands is a nightmare.

In the identical episode, Andy also had the opportunity to interview Aipda Beni Hendrik, a police officer. The latter had an accident while working and caused both his legs to be amputated. However, Aipda Beni remains a member of the police even without his legs. The Kick Andy talk show episode entitled "Disability is Not the Doomsday" as shown in Figure 3.

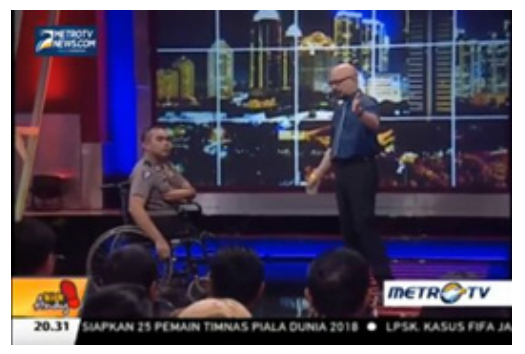

Figure 3. Aipda Beni Hendrik, in the Episode "Disability is not Doomsday."

Figure 3 shows an episode of the Kick Andy television program highlighting a disabled police officer as a guest. With the physical limitations endured by Aipda Beni, Andi asked how the response of his environment to underestimate the results of the job performance of the police who lost his legs. "It's hard to take care of himself, so how can he take care of the community, so that's how you feel? What is the judgment of the community? And it's not easy, is it?" said Andy when asking how Aipda Beni struggled with this situation. Andy's sentence can be categorized as a stereotype that people with disabilities cannot carry out their functions as humans in daily activity.

Based on observations of several episodes broadcasted in the Kick Andy television program, the researcher found that the Kick Andy program, intentionally or unintentionally, still carries a bad label on people with disabilities, even though the built narrative aims to be a source of motivation for viewers. In describing the story about the background of the guest stars presented in the program, the general prejudice about people with disabilities remained narrated. 
Although the motivations told by the guest stars in each episode have positive implications for viewers, it cannot be denied that depicting persons with disabilities who need to be sympathized or disadvantaged is still the initial narrative in building inspirational stories. Frequently, at the beginning of the interview, Andy will ask about the limitations of his guest stars and the various bitter experiences. After the informants tell their sad stories, the program will be closed with the achievements of the disabled person. This narrative model can also be noticed in one episode of the Kick Andy television program, which presents a person with a disability who has much dedication to their community, as shown in Figure 4: below:

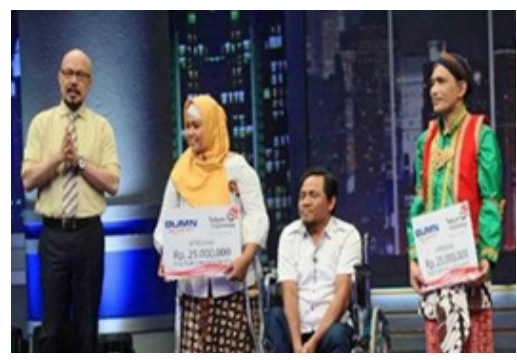

Figure 4. Risal Assor and Nurjannah, a disabled couple who work as teachers

Figure 4 above shows an episode of Kick Andy, which discusses a disabled couple who has a profession as a teacher. Although not readily demeaning disability groups on every interview opportunity, narratives to perceive sorrow for people with disabilities uses as the main formula in the performance. A similar method is commonly used in related programs, making them disable inspirational as talk show guest stars. This formula will make viewers more impressed by their conscience, compared to just conveying the achievements of the disabled without selling the sad story (Firmansyah, 2020).

\section{Conclusion}

People with disabilities rarely cover in the media, and when they appear in the media, they are regularly generalized negatively and inappropriately. We often see people with physical limitations treated as objects to have sympathized, raised goals or clinical considerations. They also introduce superheroes who have accomplished extraordinary feats to resurrect ordinary people.

The entertainment industry in Indonesian mainstream media is still dominated by "perfect" figures, with little opportunity for people with limitations. If someone is considered different, they will be naturally given the type of role dictated by them.

Instead of sympathizing with disabled people, the media should emphasize the rights disabled people should get, which are still challenging to achieve. For example, nowadays, the media rarely consider the rights of facilities for people with disabilities that should exist and accomplish in public spaces. Substantially, the content will be more beneficial for people with disabilities. Still, the media currently prefers to sell the drama of suffering experienced by people with disabilities to boost the rating figures.

\section{References}

Aini, Hanifah Risti. (2020). Citra Perempuan Difabel di Media: Sebuah Analisis Wacana Kritis. AL-IDZA'AH Jurnal Dakwah dan Komunikasi, 2(2), 12-35.

Apny, Nadine Alvira dan Nurul Hasfi. (2019). Framing Pemberitaan Isu Disabilitas Dalam Media Online Suaramerdeka.com. 
Interaksi Online, 8(1), 99-110.

Barnes, C. (1992). Disabling Imagery and the Media: An Exploration of the Principles for Media Representations of Disabled People. S.l.: BCODP.

Berger, Peter L. \& Thomas Luckmann. (2013). Tafsir Sosial atas Kenyataan: Risalah tentang Sosiologi Pengetahuan. Jakarta: LP3E.

Creswell, John .W. (2009). Research Design: Pendekatan Kualitatif, Kuantitatif, dan Mixed. Yogyakarta: Pustaka Pelajar.

Firmansyah, Dwi. (2020). Konvergesi Media Grup EMTEK dalam Pemberitaan Disabilitas. Perspektif Komunikasi: Jurnal Ilmu Komunikasi Politik dan Komunikasi Bisnis, 4(1), 61-72.

Fursich, E. (2010). Media and the representation of Others. International Social Science Journal, 61(199), 113-130.

Halimatusadiah. (2017). Dari Prasangka Hingga Diskriminasi: Menyoal Stigma Sesat dan Kekerasan Terhadap Ahmadiyah dalam Prespektif Komunikasi. Jurnal Avant Garde, 5(1), 15-34.

Haller, B.A. (2010). Representing Disability in an Ableist World. Louisville: The Avocado Press.

Internastional Labour Organization (ILO). (2014). Panduan Peliputan Disabilitas Di Indonesia. Jakarta : ILO.
Kementerian Sosial Republik Indonesia. (26 Oktober 2020). Kemensos Dorong Aksesibilitas Informasi Ramah Penyandang Disabilitas. Retrieved Oktober 3, 2021, from Data Mining Website: https://kemensos.go.id/

Littlejohn, Stephen W., Foss, Karen A. (2009). Theories of Human Communication, Seventh Edition. Long Grove, Illinois: Waveland Press Inc.

Marulitua, Bonardo. (2017). Komodifikasi, Disabilitas dan Televisi. Cakrawala Jurnal Penelitian Sosial, 5(2), 327-350.

Moleong, Lexy J. (2007). Metodologi Penelitian Kualitatif. Edisi Revisi. Bandung :PT Remaja Rosdakarya.

Nastiti, Aulia Dwi. (2013). Identitas Kelompok Disabilitas dalam Media Komunitas Online: Studi Mengenai Pembentukan Pesan Identitas Disabilitas dalam Kartunet.com. Jurnal Komunikasi Indonesia, 1(2), 31-42.

Yusuf, Muhamad Fahrudin. (2020). Citra Inferioritas Tenaga Kerja Wanita (TKW) Indonesia di Saluran Berita Sabq.Org Saudi Arabia. Komunika: Jurnal Dakwah dan Komunikasi, 14(2), 155-170.

Zhang, Lingling dan Haller, Beth. (2013). Consuming Image: How Mass Media Impact the Identity of People with Disabilities. Communication Quarterly, 61(3), 319-334. 